Notre Dame Law School

NDLScholarship

Journal Articles

Publications

1942

\title{
Religion and American Law
}

Clarence Emmett Manion

Notre Dame Law School

Follow this and additional works at: https://scholarship.law.nd.edu/law_faculty_scholarship

Part of the Jurisprudence Commons, and the Religion Law Commons

\section{Recommended Citation}

Clarence E. Manion, Religion and American Law, 22 B.U. L. Rev. 261 (1942).

Available at: https://scholarship.law.nd.edu/law_faculty_scholarship/1016

This Article is brought to you for free and open access by the Publications at NDLScholarship. It has been accepted for inclusion in Journal Articles by an authorized administrator of NDLScholarship. For more information, please contact lawdr@nd.edu. 


\section{RELIGION AND AMERICAN LAW}

\section{Clarence E. Manion*}

It is my conviction that the dean of every church-related law school in the United States is sooner or later confronted with the question that I propose to discuss today. What, if any, is the relationship of law to religion? Is not our American legal system a completely secular institution and, if this is so, then why should the study of law be sponsored by religious orders, churches and church-related universities?

Quite obviously, there are many appropriate answers to this question. I have attempted to select the one most pertinent to the theme of this conference; the one which places emphasis upon human rights and the possibility of protecting them in a war-torn world.

In the first place it is not true that American law is a secular institution. On the contrary, religion is the very bloodstream of our legal system. While it is theoretically possible to take religion out of our law, we cannot do so without destroying its very life. Oxygen may be removed from water but what remains will not quench the thirst, and, by the same token, the American constitutional system of law and government, bereft of its basic religious principle, is a complete anomaly, and something entirely different from the system to which all of us are accustomed. I have stated these propositions bluntly and unequivocally. If they are true, then we should be ready to admit that Religion is a proper predicate for practically all subjects taught and studied in the law schools of America.

I proceed to the support of these averments with a complete awareness of the realists' aversion to all a priori reasoning, and so it may be well to begin with what the realist might call an operational example. The most confirmed realist will admit that if he wakes up on a train running from New York to Boston he is riding upon a track that cannot readily be bent to point in the direction of Detroit any more than it can be made to go around in a circle. Our hypothetical traveler will know, of course, that there are other tracks pointing in other directions and that trains very similar to the one on which he is riding are running over those other tracks at that precise moment, nevertheless he happens to be using a track that leads to Boston. He can verify this by consulting his time table and checking it with the places through which he is passing.

The fact is that the object, direction and purpose of American law

*Dean, University of Notre Dame College of Law. Address delivered at the Boston University Founders' Day Panel on Legal Education, March 13, 1942. 
is as firmly and definitely fixed as the direction and destination of that New York to Boston railroad track. That object direction and purpose happens to be the ultimate eternal life of the God-created human souls with whom American law deals, for whom it functions and by whom it has been made.

It is manifest, of course, that American law is merely the implementation of American government. Any selected American law, as well as "The American Law" considered as a whole, is simply our government in action. For the force, sanction and validity of our law, or any one of our laws, we are immediately referred to the articles of our government, namely, our constitutions, state and federal. Thus the basic purpose and object of our constitutional government is at once the purpose and object of its implement; namely, our law. It is in this object and purpose of ours or any other government that we may be sure to find its basic principle. For us, this basic principle is expressed with crystal clarity in the timetable of our constitutional history.

The word principle is derived from a Latin word "principium" which signifies "a beginning". If we are seeking the principle of any institution we must look at its beginning, and at the beginning of American government we find the American Declaration of Independence speaking these words :

"We hold these truths to be self-evident; that all men are created equal; that they are endowed by their Creator with certain unalienable rights; that among these are life, liberty, and the pursuit of happiness; that to secure these rights, governments are instituted among men, deriving their just powers from the consent of the governed. ..."

Here is the track, direction and ultimate destination of the American constitutional system. The track is capable of carrying almost any type or form of governmental vehicle that is constructed or chosen from time to time by the consent of the governed. Observe, however, that both the direction and ultimate destination of this government are firmly and inflexibly fixed. The majority is powerless to change this purpose and object. Consent of the Governed-Democracy in other words-is to spend itself in bestowing upon the state the just and necessary powers with which it is to attain its unalterable ends. As to the advisability of men, measures and methods there is room for plenty of democratic argument and difference of opinion, but as to the ends, purpose and 
principles described in the Declaration as self-evident truths, the debate is foreclosed. Americans are required to take these on faith.

Let us look closely at some of these self-evident truths upon which all of our government and consequently all of our law is so squarely postulated. The first and foremost of these truths is the existence of God, the Creator. Let it be said here and now that in framing this great declaration its authors. were not composing a prayer; they were constructing an argument. They were setting up a logical justification for the separate and independent course to which they were committing the country, and as they said "to which the laws . . of God" entitled them. They made the existence of God the major premise of their argument in justification of an Independent United States. The minor premise of that argument is God's gift of equal unalienable rights to each of his creatures. The conclusion follows naturally as they expressed it, namely, that man-made government exists to protect the God-made rights of God-made men, and that if government ever becomes destructive, rather than preservative, of these ends it is the right of the people to destroy such government. Here the position of man-made government is completely subordinated to the divine end for which each man and all were created by God. Government, or the state if you please, is definitely assigned to the inferior but important role of man's agent for the protection of God's gifts. This agency extends to all of our law and all of the officers of our law from the traffic policeman on the corner to the President of the United States. All of these are charged with the single duty of safeguarding God's gifts to mankind. The second article of our American Faith is the truth that "all men are created equal". Here is the secret of what used to be called our "American Melting Pot". A lot of nonsense has been spoken and written on the subject of what is called "American Equality". Try as we may we shall never make all of our citizens equally wise or equally comfortable nor can we make strictly equal opportunities available to each and all of them. The doctrine of equality stated in the Declaration raises no such false hope. There, it is said merely that "All men are created equal". That is to say that all are equal in God's sight even though they are not equal. in the mortal sight of their fellow men. The Declaration simply tells us that every God-created human soul is just as important as any other and that as the protector of God's creative purpose with reference to mankind, the state must afford equal protection to all human beings.

This principle of the God-created equality of all men is the greatest and 
most important common denominator of our citizenship. It works upon our American Society like a catalytic agency. Constantly applied to the cloudy and complicated mixture of races and colors that has always composed our population, it produces a crystal clear solution known as American citizenship. The explosive issues of race hatred and class prejudices that constantly disturb the old world do not follow our immigrants far past our ports of entry for the sole and simple reason that here the equality of what God has made takes precedence over the distinctions and differences that man has made. Before American law and government as before his Creator, man is not a member of a class, group or race, but an individual personality with the God-given liberty necessary to achieve his divine destiny: This is why the stimulation of class consciousness and race hatred is so poisonous to and destructive of our entire American Polity. In the United States, the Brotherhood of man under the Fatherhood of God is not merely an aspiration but a basic and necessary element of our Constitutional system.

Here in the articles of our American Faith, namely, our Declaration of Independence, we find the complete philosophy of Americanism compressed into a single paragraph. Of course, it is a thoroughly religious philosophy. Ours was a revolution of believers. When the Americans of 1776 were officially told that they had no rights under the then existing British Constitution, they fell back-or rather went forward-to the laws of "Nature and of Nature's God". From that high ground it was possible to see the whole panorama of law and government in perspective and so they wrote into the Declaration not merely their Independence from England but their dependence upon God for those rights and liberties which all earthly powers must consequently respect and protect. Their experience teaches an object lesson that we should never forget, namely, that the first requisite of any real bill or declaration of rights is an act of Faith. We cannot build a safe, superstructure except upon a firm and immovable foundation. Unless human rights are anchored to God they can have no source but the state. Either man is an imperishable creature of God who hires government as his servant to protect the endowments that God had bestowed upon him or-man is simply an animal who should be managed with the same scientific ruthlessness that we apply to the barnyard. Incidentally, if the latter hypothesis is true, then Hitler is right and all of our legal and constitutional theory about the constitutional limitations upon governmental power is simply a hall-mark of Democratic inefficiency. If we expect to pre- 
serve our protective system of laws under a strictly limited government we had better take stock of ourselves and be sure that we still subscribe to the only logical reason for the existence of such a system. Religious liberty is not just one of the Four Freedoms-it is the one and only real freedom. From it all of the other liberties, so called, are logically developed. If we cannot hold our faith, we do not merely loose one article of the Bill of Rights, we drop our whole Constitutional System. As we contemplate a Bill of Rights for the world, let us remember what our forefathers found out in 1776, namely, that Faith is the subject of which every liberty is the predicate. A world that does not believe in God cannot be expected to take human rights or human freedom very seriously. 